\title{
Adsorption of $\alpha$-Chymotrypsin on Plant Biomass Charcoal
}

\author{
Hidetaka Noritomi ${ }^{*}$, Keito Hishinuma ${ }^{1}$, Shunichi Kurihara ${ }^{1}$, Jumpei Nishigami ${ }^{1}$, Tetsuya Takemoto ${ }^{2}$, \\ Nobuyuki Endo ${ }^{3}$, Satoru Kato ${ }^{1}$ \\ ${ }^{1}$ Department of Applied Chemistry, Tokyo Metropolitan University, Minami-Ohsawa, Hachioji-shi, Tokyo, Japan; ${ }^{2}$ Osaka Gas Co., \\ Ltd., Konohana-ku, Osaka, Japan; ${ }^{3}$ EEN Co., Ltd., Bunkyo-ku, Tokyo, Japan. \\ Email: "noritomi@tmu.ac.jp
}

Received June $11^{\text {th }}, 2013$; revised July $13^{\text {th }}, 2013$; accepted August $2^{\text {nd }}, 2013$

Copyright (C) 2013 Hidetaka Noritomi et al. This is an open access article distributed under the Creative Commons Attribution License, which permits unrestricted use, distribution, and reproduction in any medium, provided the original work is properly cited.

\begin{abstract}
The adsorption of $\alpha$-chymotrypsin onto plant biomass charcoal (PBC), which was prepared from plant biomass wastes such as bagasse and dumped adzuki beans by pyrolysis, has been examined. The PBC was characterized by SEM, specific surface area, and pore size distribution. The adsorption isotherms were successfully correlated by the Freundlich equation. The amount of $\alpha$-chymotrypsin adsorbed on PBC was dramatically dependent upon the solution $\mathrm{pH}$ and temperature. Maximum adsorptions of $\alpha$-chymotrypsin on adzuki bean charcoal and bagasse charcoal were observed at weak acidic and near neutral $\mathrm{pH}$, respectively. The amount of $\alpha$-chymotrypsin adsorbed on PBC decreased with an increase in the concentration of salts. Plots of the amount of $\alpha$-chymotrypsin adsorbed on PBC versus temperature exhibited an optimum temperature.
\end{abstract}

Keywords: Adsorption; Characterization; Plant Biomass Charcoal; $\alpha$-Chymotrypsin; Protein

\section{Introduction}

The use and application of boimass for renewable resources and energies are one of the most important challenges to establish a recycling society. Recently, much attention has been given to the charcoal prepared from plant biomass wastes in order to use soil amendments, adsorbents, humidity control materials, materials for wastewater treatment, and catalysts [1-6]. However, plant biomass wastes have not sufficiently been recycled yet, compared to other wastes, although an enormous amount of plant biomass waste has been discharged in the world. Moreover, the development in the high value-added function of charcoal derived from plant biomass wastes has been desired.

The adsorption of proteins onto the surface of solids has been studied extensively in the biotechnological, medical, pharmaceutical, and food fields in order to apply it to the immobilization of biocatalyst in the bioreactor, the separation of proteins, and the removal of protein contamination from food and medicine $[7,8]$. In order to assess the property of plant biomass charcoal (PBC) as a biomaterial, we have so far investigated the interaction between a protein and PBC derived from dumped adzuki

*Corresponding author. beans and so on, when hen egg white lysozyme (HEWL) was used as a model protein, and have found out that PBC effectively adsorbs HEWL, and HEWL adsorbed on PBC exhibits the enhanced storage stability at low temperatures and the excellent thermal stability at high temperatures, compared to those of native HEWL [9-11].

In the present work, to test the generality on the adsorption efficiency of PBC for proteins, we employed bovine pancreas $\alpha$-chymotrypsin as a model protein, since it is well investigated regarding its structure, functions, and properties [12]. In addition to adzuki bean charcoal and bamboo charcoal, which were used in our previous work [9], bagasse charcoal and wood charcoal have newly been used as PBC. Moreover, we investigated structural characteristics of $\mathrm{PBC}$.

\section{Experimental}

\subsection{Materials}

$\alpha$-Chymotrypsin (EC 3.4.21.1 from bovine pancreas) (type II, 52 units $/ \mathrm{mg}$ solid) was purchased from SigmaAldrich Co. Plant biomass charcoal derived from bagasses was supplied from Osaka Gas Co. Ltd. Plant biomass charcoals derived from adzuki beans, bamboos, and woods were from EEN Co. Ltd. Medicinal carbon was 

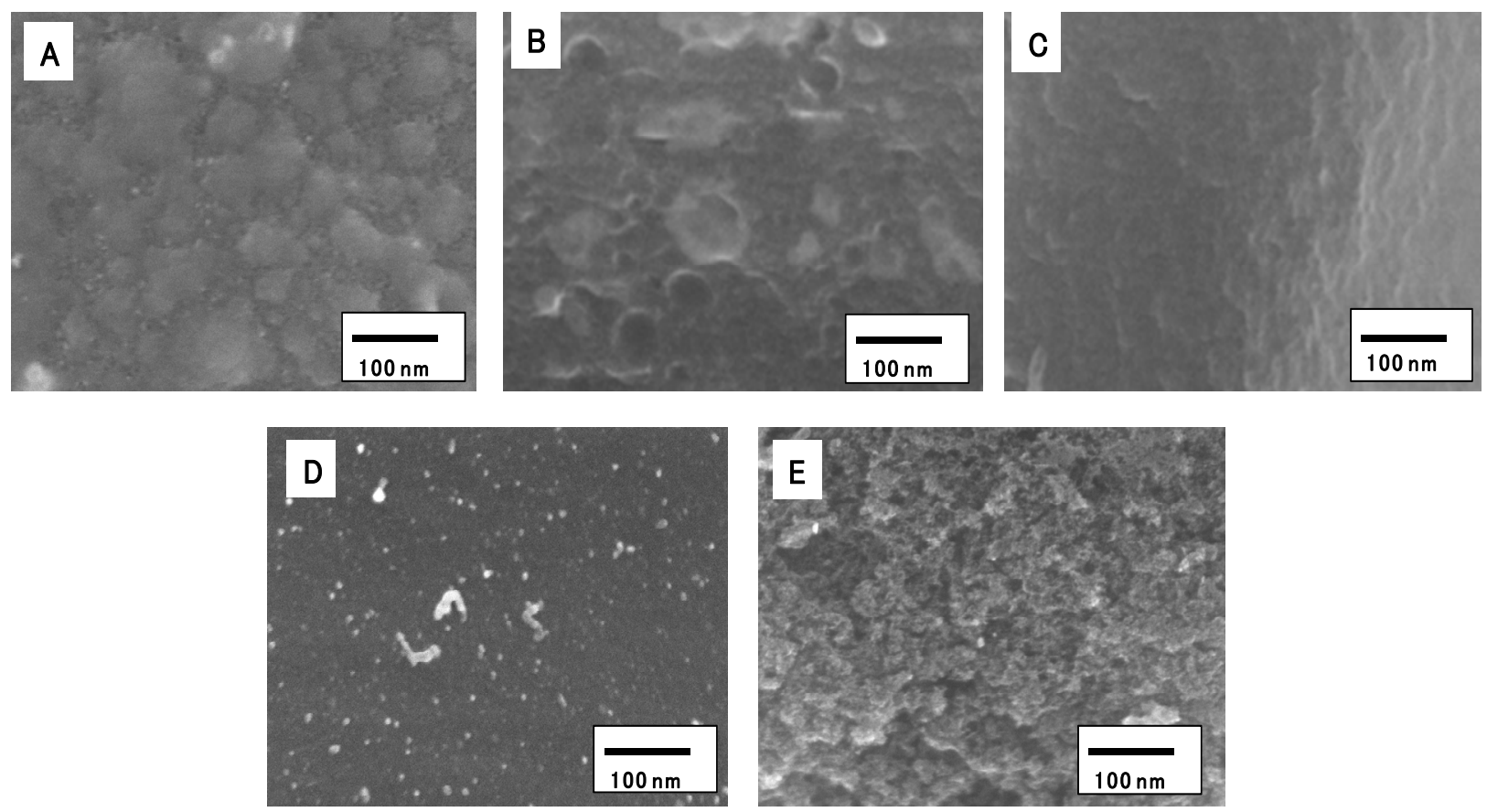

Figure 1. SEM images of (A) bagasse charcoal, (B) adzuki bean charcoal, (C) bamboo charcoal, (D) wood charcoal, and (E) medicinal carbon.

obtained from Nichi-Iko Pharmaceutical Co. Ltd.

\subsection{Characterization of Biomass Charcoal Powder}

The SEM micrograph was obtained using a scanning electron microscope (JSM-7500F FE-SEM, JEOL Ltd.) operating at 5 or $15 \mathrm{kV}$. The sample for SEM was prepared on a carbon tape without vapor deposition.

All samples were outgassed at $300^{\circ} \mathrm{C}$ for $8 \mathrm{~h}$ prior to the nitrogen adsorption measurements. The specific surface area of $\mathrm{PBC}$ was calculated with the use of the Brunauer-Emmett-Teller (BET) method using a micropore system (BELSORP-mini II, BEL JAPAN, INC.).

\subsection{Adsorption of $\alpha$-Chymotrypsin onto Plant Biomass Charcoal}

As a typical procedure, $5 \mathrm{~mL}$ of $0.01 \mathrm{M}$ phosphate buffer solution at $\mathrm{pH} 7$ containing $300 \mu \mathrm{M} \alpha$-chymotrypsin and $3 \mathrm{~g} / \mathrm{L}$ bagasse charcoal was placed in a $10-\mathrm{mL}$ test tube with a screw cup, and was incubated at $25^{\circ} \mathrm{C}$ and 120 rpm for $24 \mathrm{~h}$. After adsorption, the mixture was filtrated with a membrane filter (pore size: $0.1 \mu \mathrm{m}$, Millipore Co. Ltd.). The amount of $\alpha$-chymotrypsin adsorbed on PBC was calculated by subtracting the amount of $\alpha$-chymotrypsin included in the supernatant liquid after adsorption from the amount of $\alpha$-chymotrypsin in the aqueous solution before adsorption. The amount of $\alpha$-chymotrypsin was measured at $280 \mathrm{~nm}$ by UV/vis spectrophotometer (UV-1800, Shimadzu Co. Ltd.).
The aqueous solutions used in this study were acetate buffer solutions at $\mathrm{pH} 4$ and 5, phosphate buffer solutions

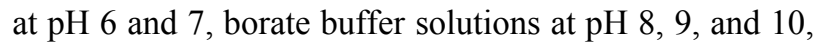
and disodium hydrogen phosphate buffer solutions at $\mathrm{pH}$ 11 and 12. The concentration of buffer solution was prepared at $0.01 \mathrm{M}$. Each data point for the amount of $\alpha$ chymotrypsin adsorbed represents an average of three measurements with a standard error less than $10 \%$.

\section{Results and Discussion}

\subsection{Characterization of Plant Biomass Charcoal}

In order to confirm the morphology of $\mathrm{PBC}$, we have obtained SEM images presented in Figure 1 for bagasse charcoal, adzuki bean charcoal, bamboo charcoal, and wood charcoal. Additionally, SEM image of medicinal carbon is shown as typical activated carbon in Figure 1. As seen in the figure, the morphology of PBC surface is strongly dependent upon the kind of materials. Bagasse charcoal was produced under $600^{\circ} \mathrm{C}$ by a charcoal kiln. Adzuki bean charcoal, bamboo charcoal, and wood char coal were prepared under $450^{\circ} \mathrm{C}$ by pyrolysis without combustion under a nitrogen atmosphere [9]. Consequently, the preparation of PBC used in the present work was not carried out by activation treatment. On the other hand, as seen in Figure 1(E), the surface of medicinal carbon was obviously much rougher than that of $\mathrm{PBC}$, and many pores were observed on the surface.

Table 1 shows the textural parameters of PBC obtained from low-temperature $\left(-196^{\circ} \mathrm{C}\right)$ nitrogen adsorption 
Table 1. Structural characteristics of PBC.

\begin{tabular}{cccc}
\hline Charcoals & Specific surface area $\left[\mathrm{m}^{2} / \mathrm{g}\right]$ & Pore volume $\left[\mathrm{cm}^{3} / \mathrm{g}\right]$ & Pore diameter peak $[\mathrm{nm}]$ \\
\hline Bagasse & 459 & 0.047 & less than 2.6 \\
Adzuki bean & $204^{\mathrm{a}}$ & - & - \\
Bamboo & 294 & 0.041 & less than 2.6 \\
Wood & 117 & 0.025 & less than 2.6 \\
Medicinal carbon & 1158 & 0.32 & less than 2.6 \\
\hline
\end{tabular}

${ }^{\mathrm{a}}$ Specific area of adzuki bean charcoal was obtained from the $\mathrm{CO}_{2}$ isotherm.

isotherms, which allow the calculation of specific surface area, specific pore volume, and pore diameter peak. In the table, the specific area of adzuki bean charcoal depicted the value obtained from the $\mathrm{CO}_{2}$ isotherm in our previous work [9], since it was too long to reach the adsorption equilibrium, and the exact value could not be obtained. The specific surface area of PBC was much smaller than that of medicinal carbon, and the specific pore volume of $\mathrm{PBC}$ was one order of magnitude lower than that of medicinal carbon. The characteristics of pores and surface chemistry of charcoal are influenced by carbonizing temperature [13]. The specific pore volume tends to increase as the carbonizing temperature of charcoal increase. It was presumed that the formation of pores of PBC was not enhanced, since PBC was prepared at low temperatures.

Figure 2 shows the pore size distribution of PBC obtained by the Barrett-Joyner-Halenda (BJH) method [14], which is based on a model of the adsorbent as a collection of cylindrical pores. The theory accounts for capillary condensation in the pores using the classical Kelvin equation, which in turn assumes a hemispherical liquidvapor meniscus and a well-defined surface tension. The pore size distribution of PBC was less than $10 \mathrm{~nm}$, while that of medicinal carbon was less than $100 \mathrm{~nm}$. Thus, the pore size of PBC was mainly in the micro-pore range, whereas that of medicinal carbon was in the meso-pore and macro-pore ranges.

\subsection{Adsorption Isotherms}

We used $\alpha$-chymotrypsin as a model protein. The amount of $\alpha$-chymotrypsin adsorbed on BCP increased with an increase in the time of adsorption, and reached a plateau around $24 \mathrm{~h}$. Figure 3 shows the amount of $\alpha$-chymotrypsin adsorbed on PBC. The amount of $\alpha$-chymotrypsin adsorbed varied with the kind of materials. As seen in Figure 3, the sequence of the amount adsorbed went as follows: medicinal carbon $>$ bagasse charcoal $>$ wood charcoal $>$ adzuki bean charcoal $>$ bamboo charcoal, while that of the specific surface area went as follows: medicinal carbon $>$ bagasse charcoal $>$ bamboo charcoal $>$ adzuki bean charcoal $>$ wood charcoal, as shown

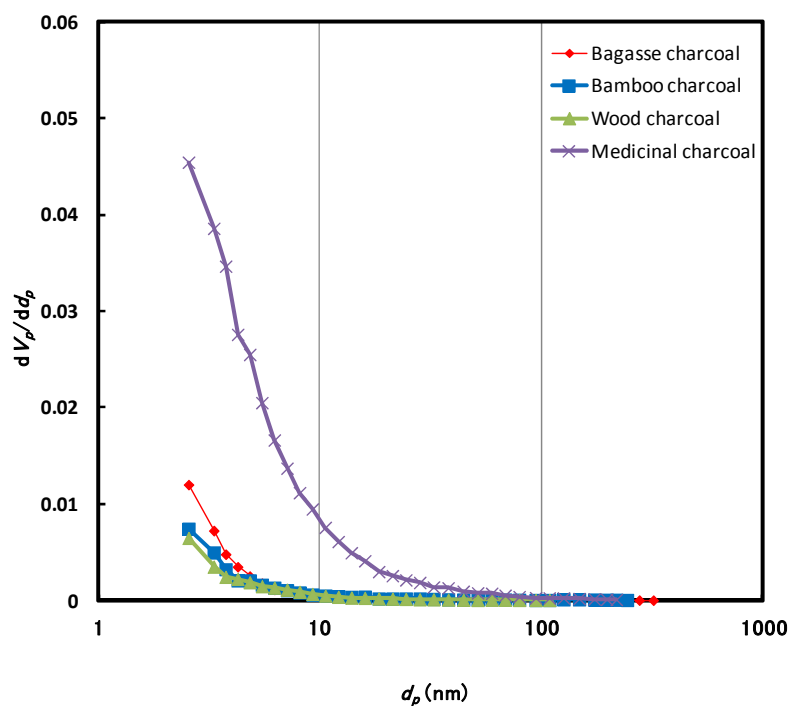

Figure 2. Pore size distribution of plant biomass charcoals.

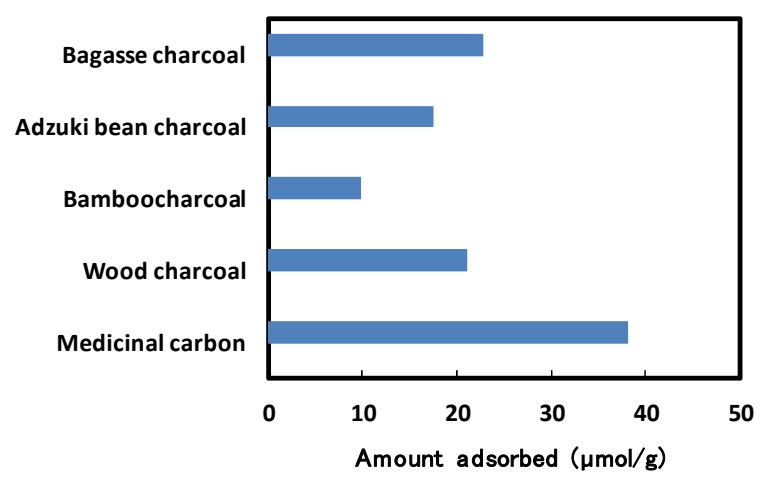

Figure. 3 Effect of the kind of materials on the amount of $\alpha$-chymotrypsin adsorbed; adsorption was carried out by incubating buffer solution ( $\mathrm{pH}$ 7) containing $300 \mu \mathrm{M} \alpha$ chymotrypsin and $3 \mathrm{~g} / \mathrm{L}$ PBC or medicinal carbon at 120 rpm and $25^{\circ} \mathrm{C}$ for $24 \mathrm{~h}$.

in Table 1. Concerning PBC, the amount adsorbed did not correspond to the specific surface area. As seen in Figures 1 and 2, the morphology of PBC surface and the pore size distribution of PBC markedly depended upon the kind of raw materials. Consequently, it is assumed that they affect the adsorption efficiency of PBC. The 
amount of $\alpha$-chymotrypsin on bagasse charcoal was 0.6 fold that on medicinal carbon, although the surface area of medicinal carbon was about 2.5 times larger than that of bagasse charcoal. The scale of $\alpha$-chymotrypsin is $5.1 \times$ $4.0 \times 4.0 \mathrm{~nm}[12]$. Thus, it is considered that pores having less than the size of proteins do not work effectively against the adsorption of proteins. This indicates that bagasse charcoal has reasonable adsorption efficiency for $\alpha$-chymotrypsin.

Figure 4 shows the adsorption isotherms of $\alpha$-chymotrypsin on adzuki bean charcoal and bagasse charcoal. These isotherms exhibit a gradual increase. The amount of $\alpha$-chymotrypsin adsorbed on bagasse charcoal is superior to that of $\alpha$-chymotrypsin adsorbed on adzuki bean charcoal. The solid lines presented in the figure are the best fit Freundlich isotherm characterization of the experimental data using Equation (1).

$$
W=K_{\mathrm{F}} C^{1 / n}
$$

Here, $W$ is the amount of $\alpha$-chymotrypsin adsorbed on $\mathrm{PBC}, C$ is the $\alpha$-chymotrypsin concentration, and $K_{\mathrm{F}}$ and $n$ are experimental constants [15]. The correlation constants $\left(r^{2}\right)$ of adzuki bean charcoal and bagasse charcoal were both 0.990 . With regard to other adsorption isotherm models, for example, when the data were fitted for the adsorption isotherm model of Langmuir, the correlation constants $\left(r^{2}\right)$ of adzuki bean charcoal and bagasse charcoal were 0.853 and 0.815 , respectively. The present isotherm type was similar to that of the adsorption of HEWL onto PBC, and $\alpha$-chymotrypsin was more effectively adsorbed on PBC, compared with HEWL [9]. The isotherm of bagasse charcoal displayed upward curvature, compared to that of adzuki bean charcoal. This indicates

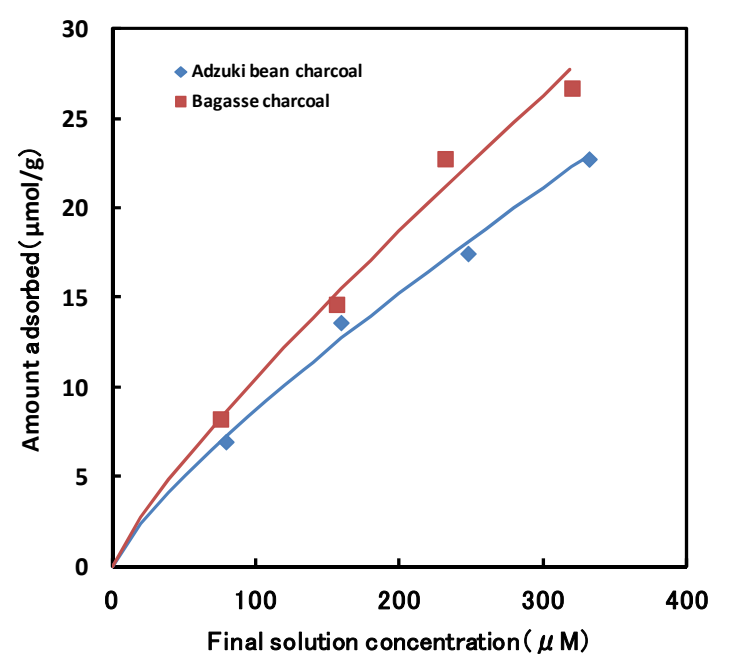

Figure 4. Adsorption isotherms of $\alpha$-chymotrypsin on adzuki bean charcoal and bagasse charcoal; adsorption was carried out by incubating buffer solution ( $\mathrm{pH} 7$ ) containing a certain amount of $\alpha$-chymotrypsin and $3 \mathrm{~g} / \mathrm{L} \mathrm{PBC}$ at 120 rpm and $25^{\circ} \mathrm{C}$ for $24 \mathrm{~h}$. that the adsorption of $\alpha$-chymotrypsin on bagasse charcoal is more effective than that on adzuki bean charcoal.

\subsection{Effect of pH Value on $\alpha$-Chymotrypsin Adsorption}

Figure 5 shows the relationship between the $\mathrm{pH}$ value of aqueous solutions and the amount of $\alpha$-chymotrypsin adsorbed on adzuki bean charcoal and bagasse charcoal at $25^{\circ} \mathrm{C}$. The amount of $\alpha$-chymotrypsin adsorbed on bagasse charcoal sharply increased with an increase in the $\mathrm{pH}$ value, reaching the optimum value around neutral $\mathrm{pH}$, and tended to decrease in the alkaline region. The $\mathrm{pH}$ profile in the case of adzuki bean charcoal was similar to that in the case of bagasse charcoal, although the optimal value of adzuki bean charcoal is slightly shifted to acidic $\mathrm{pH}$, compared to that of bagasse charcoal. The $\mathrm{pH}$ profile in the adsorption of $\alpha$-chymotrypsin on PBC was similar to that in the adsorption of HEWL on PBC [9]. The net charge on the protein molecules is varied by adjusting the $\mathrm{pH}$ of the solution, since the protein molecule is constructed by amino acid residues containing positive- and negative-charged side chains. $\alpha$-Chymotrypsin belongs to basic proteins, and the isoelectric point (pI) of $\alpha$-chymotrypsin is 9.1 [12]. The lower the $\mathrm{pH}$ of solution containing $\alpha$-chymotrypsin becomes below the pI of $\alpha$-chymotrypsin, the more positive the net charge of $\alpha$-chymotrypsin becomes. The $\zeta$ potential of PBC drastically decreases with increasing the $\mathrm{pH}$ value, exhibiting a negative value above $\mathrm{pH} \mathrm{4,} \mathrm{drops} \mathrm{till} \mathrm{pH} \mathrm{7,} \mathrm{and} \mathrm{is} \mathrm{almost} \mathrm{con-}$ stant in the alkaline region [9]. When the $\mathrm{pH}$ value was around the $\mathrm{pI}$ of $\alpha$-chymotrypsin or the $\mathrm{pH}$ where the $\zeta$

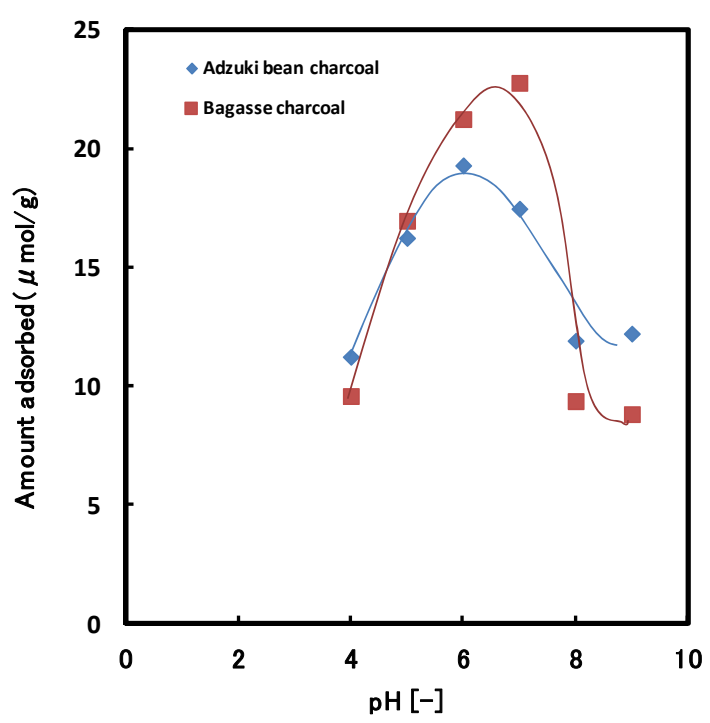

Figure 5. Effect of pH on the amount of $\alpha$-chymotrypsin adsorbed on adzuki bean charcoal and bagasse charcoal; adsorption was carried out by incubating buffer solution (appropriate $\mathrm{pH}$ ) containing $300 \mu \mathrm{M} \alpha$-chymotrypsin and $3 \mathrm{~g} / \mathrm{L}$ $\mathrm{PBC}$ at $120 \mathrm{rpm}$ and $25^{\circ} \mathrm{C}$ for $24 \mathrm{~h}$. 
potential of PBC approached 0 volts, a dramatic decrease in the amount adsorbed was observed. The electrostatic interaction between the positive charge of $\alpha$-chymotrypsin and the negative charge on PBC tends to decrease in the region of acidic or alkaline $\mathrm{pH}$. Therefore, in the vicinity of neutral $\mathrm{pH}$ where the Coulomb force between PBC and $\alpha$-chymotrypsin is high, a high amount of adsorption tends to be obtained. Consequently, the adsorption profiles seem to be related mainly with the electrostatic interaction.

\subsection{Effect of Ionic Strength on $\alpha$-Chymotrypsin Adsorption}

Figure 6 shows the relationship between the $\mathrm{KCl}$ concentration of the solution and the amount of $\alpha$-chymotrypsin adsorbed on adzuki bean charcoal and bagasse charcoal. The amount of $\alpha$-chymotrypsin adsorbed on $\mathrm{PBC}$ decreased with an increase in $\mathrm{KCl}$ concentration. The solutions of $\alpha$-chymotrypsin at the $\mathrm{KCl}$ concentration employed at the present work were transparent, and no precipitate was observed. At first, it is considered that an increase in the ionic strength results in a decrease in the electrostatic interaction due to the electrostatic screening effect. Many radical species due to functional groups containing oxygen atoms, which are formed by thermal decomposition of cellulose and hemicelluloses, are detected in charcoals carbonized at $500^{\circ} \mathrm{C}$ by the measurement of electron spin resonance, and functional groups decrease with increasing carbonization temperature [13, 16]. We have reported that the elemental ratio of oxygen on the surface of $\mathrm{PBC}$ was more than $15 \%$, and $\mathrm{C}-\mathrm{O}$,

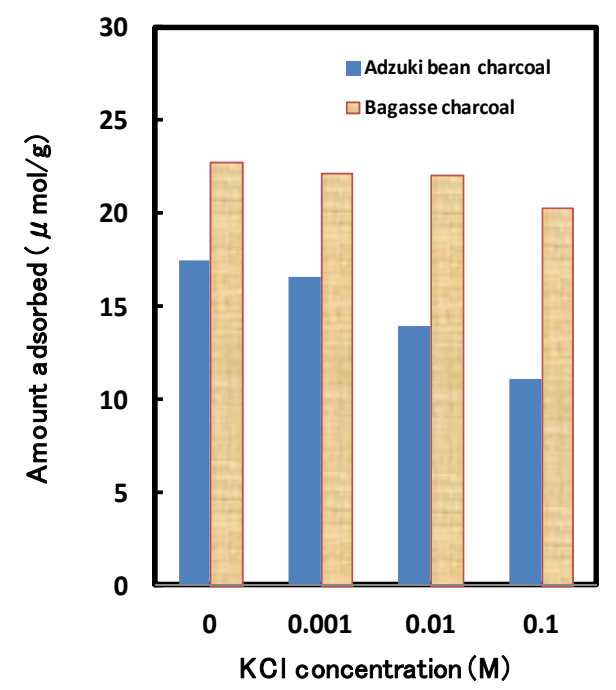

Figure 6. Effect of $\mathrm{KCl}$ concentration on the amount of $\alpha$ chymotrypsin adsorbed on adzuki bean charcoal and bagasse charcoal; adsorption was carried out by incubating buffer solution (pH 7) containing $300 \mu \mathrm{M} \alpha$-chymotrypsin, 3 $\mathrm{g} / \mathrm{L} \mathrm{PBC}$, and a certain amount of $\mathrm{KCl}$ at $120 \mathrm{rpm}$ and $25^{\circ} \mathrm{C}$ for $24 \mathrm{~h}$.
$\mathrm{O}-\mathrm{C}-\mathrm{O}, \mathrm{C}=\mathrm{O}$, and $\mathrm{COOH}$ were detected by $\mathrm{X}$-ray photoelectron spectroscopy [9]. Consequently, it is suggested that electrostatic interactions and hydrogen bondings via functional groups on the surface of PBC largely contribute to the adsorption of $\alpha$-chymotrypsin, since $\alpha$-chymotrypsin has many ionic and hydroxyl amino acid residues, as seen in Figure 7. Thus, the addition of inorganic salts appears to weaken those interactions between PBC and $\alpha$-chymotrypsin.

\subsection{Effect of Temperature on $\alpha$-Chymotrypsin Adsorption}

Figure 8 shows the plots of the amount of $\alpha$-chymotrypsin adsorbed on adzuki bean charcoal and bagasse charcoal against the adsorption temperature. The amount of $\alpha$-chymotrypsin adsorbed on PBC was dramatically influenced by the temperature. The maximum amounts of $\alpha$-chymotrypsin adsorbed on adzuki bean charcoal and bagasse charcoal were both observed around $25^{\circ} \mathrm{C}$. This tendency was similar to the case of the adsorption of HEWL onto PBC [9]. The temperature profile on the amount of proteins adsorbed on the water-insoluble matrix tends to exhibit an optimum temperature, since the conformation of proteins is generally sensitive to temperature [17]. The state on the surface of protein molecules

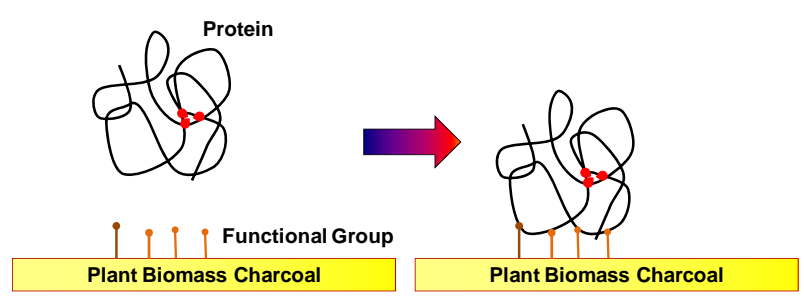

Figure 7. Schematic representation of adsorption of proteins onto the surface of PBC.

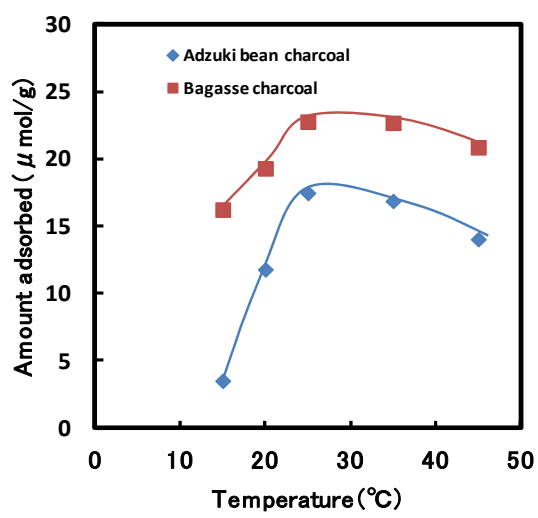

Figure 8. Effect of temperature on the amount of $\alpha$-chymotrypsin adsorbed on adzuki bean charcoal and bagasse charcoal; adsorption was carried out by incubating buffer solution (pH 7) containing $300 \mu \mathrm{M} \alpha$-chymotrypsin and 3 $\mathrm{g} / \mathrm{L} \mathrm{PBC}$ at $120 \mathrm{rpm}$ and an appropriate temperature for 24 h. 
such as the charge, hydrophilicity, and hydrophobicity due to their conformation affects the interaction of proteins with matrices. Moreover, the sufficient potential to weaken the hydration layer around a protein molecule is necessary to enhance the interactions between the amino acid residues of proteins and functional groups on the surface of PBC. Therefore, since the entropy effect of protein and the enthalpy effect of adsorption phenomenon are involved in the adsorption, the adsorption profile tends to exhibit the maximum at an appropriate temperature.

\section{Conclusion}

PBC had the adsorption efficiency for proteins, similar to medicinal carbon. The adsorption isotherms followed the Freundlish equation. PBC exhibited the optimum $\mathrm{pH}$ on the amount adsorbed due to the interaction between $\alpha$ chymotrypsin and $\mathrm{PBC}$, such as the electrostatic force, the hydrogen bonding. The adsorption temperature markedly affected the amount adsorbed.

\section{Acknowledgements}

This work was supported by a Grant-in-Aid for Scientific Research (C) from Japan Society for the Promotion of Science (No. 24561013).

\section{REFERENCES}

[1] A. Cross and S. P. Sohi, "The Priming Potential of Biochar Products in Relation to Labile Carbon Contents and Soil Organic Matter Status," Soil Biology \& Biochemistry, Vol. 43, No. 10, 2011, pp. 2127-2134. http://dx.doi.org/10.1016/j.soilbio.2011.06.016

[2] L. L. Pulido, T. Hata, Y. Imamura, S. Ishihara and T. Kajimoto, "Removal of Mercury and Other Metals by Carbonized Wood Powder from Aqueous Solutions of their Salts," Journal of Wood Science, Vol. 44, No. 3, 1998, pp. 237-243. http://dx.doi.org/10.1007/BF00521970

[3] I. Abe, M. Hitomi, N. Ikuta, I. Kawafune, K. Noda and Y. Kera, "Humidity-Control Capacity of Microporous Carbon," Seikatsu Eisei, Vol. 39, No. 6, 1995, pp. 333-336.

[4] B. Khalfaoui, A. H. Meniai and R. Borja, "Removal of Copper from Industrial Wastewater by Raw Charcoal Obtained from Reeds," Journal of Chemical Technology and Biotechnology, Vol. 64, No. 2, 1995, pp. 153-156. http://dx.doi.org/10.1002/jctb.280640207

[5] M. Yatagai, R. Ito, T. Ohira and K. Oba, "Effect of Charcoal on Purification of Wastewater," Mokuzai Gakkaishi, Vol. 41, No. 4, 1995, pp. 425-432.

[6] H. Kominami, K. Sawai, M. Hitomi, I. Abe and Y. Kera, "Reduction of Nitrogen Monoxide by Charcoal," Nippon Kagakukaishi, No. 6, 1994, pp. 582-584. http://dx.doi.org/10.1246/nikkashi.1994.582

[7] C. Haynes and W. Norde, "Structure and Stabilities of Adsorbed Proteins," Journal of Colloid and Interface Science, Vol. 169, No. 2, 1995, pp. 313-328. http://dx.doi.org/10.1006/jcis.1995.1039

[8] K. Nakanishi, T. Sakiyama and K. Imamura, "On the Adsorption of Proteins on Solid Surfaces, a Common but Very Complicated Phenomenon," Journal of Bioscience and Bioengineering, Vol. 91, No. 4, 2001, pp. 233-244.

[9] H. Noritomi, D. Iwai, R. Kai, M. Tanaka and S. Kato, "Adsorption of Lysozyme on Biomass Charcoal Powder Prepared from Plant Biomass Wastes," Journal of Chemical Engineering of Japan, Vol. 46, No. 3, 2013, pp. 196-200. http://dx.doi.org/10.1252/jcej.12we182

[10] H. Noritomi, R. Ishiyama, R. Kai, D. Iwai, M. Tanaka and S. Kato, "Immobilization of Lysozyme on Biomass Charcoal Powder Derived from Plant Biomass Wastes," Journal of Biomaterials and Nanobiotechnology, Vol. 3, No. 3, 2012, pp. 446-451.

http://dx.doi.org/10.4236/jbnb.2012.34045

[11] H. Noritomi, R. Kai, D. Iwai, H. Tanaka, R. Kamiya, M. Tanaka, K. Muneki and S. Kato, "Increase in Thermal Stability of Proteins Adsorbed on Biomass Charcoal Powder Prepared from Plant Biomass Wastes," Journal of Biomedical Science and Engineering, Vol. 4, No. 11, 2011, pp. 692-698. http://dx.doi.org/10.4236/jbise.2011.411086

[12] A. Kumar and P. Venkatesu, "Overview of the Stability of $\alpha$-Chymotrypsin in Different Solvent Media," Chemical Reviews, Vol. 112, No. 7, 2012, pp. 4283-4307. http://dx.doi.org/10.1021/cr2003773

[13] T. Asada, S. Ishihara, T. Yamane, A. Toba, A. Yamada and K. Oikawa, "Science of Bamboo Charcoal: Study on Carbonizing Temperature of Bamboo Charcoal and Removal Capability of Harmful Gases," Journal of Health Science, Vol. 48, No. 6, 2002, pp. 473-479.

http://dx.doi.org/10.1248/jhs.48.473

[14] E. P. Barrett, L. G. Joyner and P. H. Halenda, "The Determination of Pore Volume and Area Distributions in Porous Substances. I. Computations from Nitrogen Isotherms," Journal of the American Chemical Society, Vol. 73, No. 1, 1951, pp. 373-380. http://dx.doi.org/10.1021/ja01145a126

[15] W. Adamson, "Physical Chemistry of Surfaces," 4th Edition, John Wiley \& Sons, New York, 1982, p. 373.

[16] K. Nishimiya, T. Hata, Y. Imamura and S. Ishihara, "Analysis of Chemical Structure of Wood Charcoal by X-Ray Photoelectron Spectroscopy," Journal of Wood Science, Vol. 44, No. 1, 1998, pp. 56-61. http://dx.doi.org/10.1007/BF00521875

[17] W. Norde and J. Lyklema, "The Adsorption of Human Plasma Albumin and Bovine Pancreas Ribonuclease at Negatively Charged Polystyrene Surfaces," Journal of Colloid and Interface Science, Vol. 66, No. 2, 1978, pp. $257-$ 265. http://dx.doi.org/10.1016/0021-9797(78)90303-X 